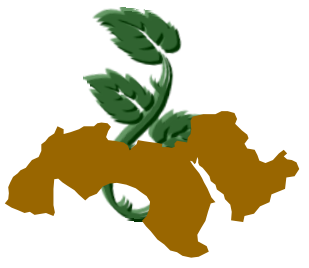

Arab Univ. J. Agric. Sci., Ain Shams Univ., Cairo, 23(1), 51 - 60, 2015

\title{
EFFECT OF VINE BUD LOAD ON BUD BEHAVIOR, YIELD, AND CLUSTER CHARACTERISTICS OF AUTUMN ROYAL SEEDLESS GRAPEVINES
}

\author{
Abdle Hamid ${ }^{1}$, N.; Samah, I. Nasr ${ }^{2}$ and H.M. Korkar ${ }^{3}$ \\ 1. Department of Hort. Faculty of Agric., Ain Shams Univ., Cairo, Egypt \\ 2. Ministry of Agriculture, C.A. Afforestation and Environment, Egypt \\ 3. Higher Institute for Agric. Co-Operation, Cairo, Egypt
}

Keywords: Grapevine, winter pruning, Autumn Royal seedless grapes, bud load, fruit quality

\section{ABSTRACT}

This study was conducted through the seasons of 2013 and 2014 to determine the optimum bud loads/ vine for Autumn Royal seedless "grapevines. Three years old uniform vines were uniform chosen and pruned to four levels of bud load, namely (32, 42, 52 and 60 buds/ vine). With fruiting spur at 2, 3 and 4 buds per spur

The results showed that the percentage of bursted buds was decreased significantly by increasing bud load/vine in the two seasons of the study. Data also indicated that 42 buds/ vine were more suitable for Autumn Royal seedless grapevines to produce good yield and fruit quality. On the other hand, 32 buds/vine or 60 buds/vine were unfavorable science it produced rather clusters.

In addition, pruning Autumn Royal seedless "grapevines to 42 buds /vine by leaving 21 spur with 2 eyes/spur or leaving 14 spur with 3 eyes per spur resulted a high yield and good quality, reduced cluster compactness and reduced shoot berries \%, gave the greatest cluster weight, berry firmness, adherence, T.S.S and anthocyanin content. Increasing bud load increased number of cluster/vine and yield but reduced cluster weight. Vines pruned to 32 buds / vine gave the greatest $\mathrm{C} / \mathrm{N}$ ratio of the canes. Whereas vines pruned to 60 buds / vine showed higher percent of T.A than the other levels of bud load and cane length.

\section{INTRODUCTION}

(Received 1 February, 2015)

(Accepted 10 February, 2015)
Grape is one of the most favored fruits in this field. Grapevine (Vitis vinifera, L.) is considered one of the most important fruit crops in the world and the second major fruit crops in Egypt after citrus. Egypt takes an important position in viticulture of the world and ranks $13^{\text {th }}$ place in grape production

Autumn Royal seedless is one of the new cultivars which were introduced to Egypt, this black seedless grape is known for its black berries which ripen in late September to mid-October. They are conical in shape and are known for their very distinct flavor. Adjusting of bud load of this important grape $\mathrm{cv}$ is need for grape growers

Good results depend on the vegetative - productive behaviour of the vineyard. Di Lorenzo et al (2011). Therefore, it is necessary to maximize its production with high quality, through several ways especially horticultural practices. Regulating bud loads is one of the critical parameters to obtain the optimal balance of yield and fruit quality Fawzi et al (1984 a) and Marwad et al (1993). Pruning is considered the most important practice through which grape production can be increased and cluster quality improved. El-Baz et al (2002); Brown and Gao (2004); Elbotaty (2007); Fawzi et al (2010) and Cangi and Kilic (2011). The number of nodes retained per cane or spur also affects grape yields. There is a need to evaluate the optimum pruning severity and cane length (Cawthon and Morris, 1977 and Morris et al 1984).

It is widely accepted that the fruit yield and fruit quality of grapevine is related to the number of bud retained at dormant pruning (Al- Wan, 1990; Zieg- 
ler, 1991 and El-Hammady \& Abdel-Hamid, 1995).

Spur pruning is used on cultivar having large clusters and fruitful basal buds i.e. Flame seedless, King, s Ruby and Romi Red. on the other hand, cane pruning is used on cultivars in which the basal buds are less fruitful. Pruning is considered the most important practice through which grape production can be increased and cluster quality improved. The basal 3-4 buds of the cultivar are less fruitful, so using long fruit canes is important for production normal crop. Bud load is the most important factor affecting yield and cluster quality as well as vine vigor of Thompson seedless grapevines Marwad et al (1993); El-Hammady \& Abdel-Hamid, 1995) \& Omar and Abdel-kawi, 2000; Rubio et al (2002) Fawzi et al 2010 on Tempranillo variety and El-Baz et al (2002) on Crimson seedless grapevines.

The objective of this study is to determine the optimum bud load per vine for Autumn Royal seedless grape and to study the effect of bud load on bud behavior, cluster quality, yield per vine and total carbohydrates. For this promising grape cultivar

\section{MATERIALS AND METHODS}

Two successive seasons were conducted during 2013 and 2014 in a private vinevard. At CairoAlexandria desert road, Giza Governorate, Egypt. The vines were Autumn Royal seedless cv., 3years old .Vines were planted at $1.5 \times 3.0$ meters in a sandy soil and the drip irrigation system was adopted and subjected to the normal horticultural managements and supported according to the Spanish Paron trellising system. Vines were chosen as to be nearly similar in growth and vigour. and pruned during the last week of December for the two seasons

This experiment was to study the effect of pruning severity (Four bud load 32, 42, 52 and 60 buds / vine were adopted and three levels of spur length (2, 3 and 4 eyes / spur) on fruiting and quality of " Autumn Royal " grapevine.

Number of renewal spurs (2 nodes) were retaind per vine according to bud load under study. A randomized complete block design with four replicates and one vines per each replicate was used. ( 4 bud load levels $\times 3$ spur length $\times 4$ replicates) The studied treatment are shown in Table (1).

Table 1. Pruning severity used for Autumn Royal grapevines

\begin{tabular}{|ccc|}
\hline $\begin{array}{c}\text { No. of eyes } \\
\text { per vine }\end{array}$ & $\begin{array}{c}\text { No. of eyes } \\
\text { per spur }\end{array}$ & No. of spur \\
\hline \multirow{3}{*}{32} & 2 & 16 \\
& 3 & 11 \\
4 & 8 \\
\hline \multirow{3}{*}{42} & 2 & 21 \\
& 3 & 14 \\
& 4 & 10 \\
\hline 52 & 2 & 26 \\
& 3 & 17 \\
& 4 & 13 \\
\hline 60 & 2 & 30 \\
& 3 & 20 \\
& 4 & 15 \\
\hline
\end{tabular}

The following parameters were measured to evaluate the tested treatments:

\section{1- Budburst and Bud fertility \%}

The percentage of opening buds (bud burst) and bud fertility were calculated according to Sourial et al (1993) as follows:

Bud burst $\%=\frac{\text { Number of bursted buds }}{\text { Total number of buds }} \times 100$

Bud fertility $\%=\frac{\text { Number of fruiting buds }}{\text { Total number of buds }}$

\section{3- Yield and fruit quality}

At harvest time (17-19\% TSS; 0.4-0.5 \% acidity and 45-49 T.S.S /acid ratio, nearly at the first week of Oct for both seasons. The total yield $(\mathrm{kg}$ /vine) was determined by weight. However, number of clusters per vine and average cluster weight (g) were determined and recoded. A sample of 2 clusters was taken at random from the harvested clusters of each replicate and taken to laboratory in the Horticultural Department, Faculty of Agriculture, Ain Shams University to determine the following characters:

\section{a. Physical characteristics of berries}

- Cluster compactness coefficient: average number of berries per cluster were counted to 
determine clusters compactness using the following equation according to Ali et al (2000).

Cluster compactness coefficient $=$

$$
\frac{\text { Number of bursted per cluster }}{\text { clusterlength }(\mathrm{cm})} \times 100
$$

Shot berries per cluster: =

$$
\frac{\text { Number of } \text { shot berries per }{ }^{-} \text {cluster }}{\text { Total number of berries per clusterr }} \times 100
$$

- Berry firmness $\left(\mathbf{g} / \mathrm{cm}^{2}\right)$ : was determined by using Shatilan's instrument.

- Berry juice \%: Berry juice was extracted and filtered through two layers of cheese cloth to determine Berry juice $\%$ as follows.

Berry juice \% =

$$
\frac{\text { Weightof } 100 \text { berries juice }(\mathrm{g})}{\text { Weight of } 100 \text { berries }(\mathrm{g})} \times 100
$$

\section{b. Chemical characteristics of berries}

Total soluble solids (TSS\%) were determined using a hand refractmeter and the percentage of acidity (as $\mathrm{g}$ tartaric acid/100 $\mathrm{ml}$ juice) by titration with $0.1 \mathrm{~N}$ Sodium hydroxide was determined in fruit juice (A.O.A.C. 1980). Total anthocyanin (mg/100 $\mathrm{g}$ fresh weight) as described by Yilids \& Dikmen (1990).

\section{Vegetative growth parameters}

Leaf of the apical $5^{\text {th }}$ and $6^{\text {th }}$ leaves at first of September for both studied seasons was chosen to measure leaf area and chlorophyll content was measured.

a. Average leaf area/shoots $\left(\mathrm{cm}^{2}\right)$ of the leaves using a Cl-203- laser Area-meter made by CID, Inc., Vancouver, USA.

b. Chlorophyll content in SPAD - 501 MINOLTA readings (as an indication for chlorophyll content). SPAD readings were transformed to $\mathrm{mg} / \mathrm{m}^{2}$ according to the equation: $\mathrm{Chl}=-80.05+$ 10.40 [SPAD - 502] (Monje and Bugbee, 1992).

\section{Chemical analysis}

Total carbohydrates in one-year-old spur as $\mathrm{mg} / \mathrm{g}$ dry weight were determined colorimetically by using reagent according to the method described by Herbert et al (1971). Total nitrogen in leaves were determined colorimetrically using reagent and counted as $\mathrm{mg} / \mathrm{g}$ dry weight according to the method described by Pregel 1945. However, the ratio of total carbohydrates to total nitrogen $(\mathrm{C} / \mathrm{N}$ ratio) was calculated by dividing the percentage of total carbohydrates on the percentage of total nitrogen.

\section{Statistical analysis}

Data were then analyzed for statistical significant differences using Duncan's multiple range tests. The standardized least significant range (L.S.R) at 5\% level was used to compare the effect of various treatments according to (Sendecor and Cochran, 1982).

\section{RESULTS AND DISCUSSION}

\section{Bud behavior $\%$}

Results presented in Table (2) showed the effect of vine bud load and spur length on bud behaviour of " Autumn Royal " grapevines in 2013 and 2014 seasons

It was evident from the data that, vines pruned to $42 \mathrm{bud} / \mathrm{vine}$ exhibited the highest values of bud burst percentage with all of spur length, followed by 52 and 32 bud/vine without significant different between. Whereas $60 \mathrm{bud} /$ vine give the low percentage of bud burst them.

The highest value of bud burst was noticed with the pruned vine at 2 and 3 eyes per spur plus 42 buds. On the other hand, the lowest value of bud burst was noticed with the pruned vine at all eyes (2, 3 and 4 ) plus 60 buds. The same results were obtained by Christensen et al (1994) \& ElHammady \& Abdel-Hamid, 1995) and Omar \& Abdel-kawi (2000) showed that increasing bud load induced lower percentage of bud burst. In addition, Ahmad et al (2004) reported that pruning severity (three levels of pruning viz. spurs pruned to 6,8 and 10 nodes) had no effect on bud burst of Perlette grapes.

As regarded percentages of bud fruitfulness, it is clear from that Percentage of bud fruitfulness were affected by bud load/ vine \& spur length in this respect, the highest values were (88.40 \& $90.13 \%$ ) for (42 buds/vine and 3 buds/spur) in the two seasons, respectively. On the other hand, vines pruned to (60 buds/vine \& 4 buds/spur) gave lower bud fruitfulness percentage (80.95 \& 
$83.54 \%)$ at the two seasons of study. The obtained data go in line with those reported by Salem et al (1997) mentioned that when Thompson seedless grapevine were pruned to $72,84,96,108$ buds per vine, leaving 96 or 108 buds produced the greatest growth and the lowest percentage of fruitful buds. Also Fawzi et al (2010) reported that the low fruitfulness of Crimson seedless grape was due to the high vigor vine, whereas moderated vigor produced usually more fruitful. According to the foregoing results, it could be conclude that "Autumn Royal" grapevines, which have high growth, get low fruitfulness, whereas the moderated vigor ones are usually more fruitful.

Regarding effect of vine bud load and length spur on leaf area $\left(\mathrm{cm}^{2}\right)$. The greatest value of leaf area (1238. 3 and $127.7 \mathrm{~cm}^{2}$ ) resulted from the vines pruned to (42 buds/vine \& 2 and 3 buds/spur) flowed by vines pruned to (32 buds/vine $\&$ with all eyes of spur) in first and second season, respectively. On the other hand, the lowest values of leaf area ( 82.1 and $82.43 \mathrm{~cm}^{2}$ ) were recorded with vine pruned to 60 buds/vine with 3 and 4 eyes per spur in first season and vine pruned at 3 eyes per cane in the second season, respectively. Slight differences were noticed in leaf area with vines pruned to 52 buds/vine .In this respect, Cangi and Kilic (2011) and Shalan (2013) reported that mean leaf area decreased with increasing of bud loading levels. Also Bodor et al (2013) found that in the case of the ampelometric variability caused by pruning level/bud load, it can be concluded that the morphological characteristics of the leaves can be divided into two groups, viz. stable (angles between the veins, depths of sinuses) and variable (single leaf area and lengths of veins and petioles). Stable characteristics could serve as descriptors of varietal identification, whereas variable properties may depend on cultivation practices.

Data of leaf chlorophyll content showed that, no significant differences were noticed in among all vines pruned under study. The highest values of leaf chlorophyll content were observed with the pruned vine at 3 eyes plus 32 bud / vine in the two seasons it is recorded (357.6 \& 365.9 and $355.5 \mathrm{mg} / \mathrm{m}^{2}$ ), respectively. However, vines pruned to 60 buds/ vine and 4 buds/spur resulted the least leaf chlorophyll content.
Concerning total carbohydrates, it is clear from Table (3) that no significant effect to bud load or spur length in the two seasons of the study. However, the highest values were $(17.21 \& 17.36 \%)$ for (42 buds/vine and 3 buds/spur) in the two season, respectively.

Nitrogen percentage, in 1-year-old wood significantly affected by number and spur length. Vines pruned to 32 and 42 buds/ vine plus 2 and 3 eyes per spur recorded the highest values of nitrogen \% where it were $(2.92 \& 2.96 \%$ and $2.92 \& 2.80)$ in the first seasons, respectively. leaving 20 or 15 spur/ vine with 3 or 4 eyes per spur produced a lower nitrogen \% than the other vines In this respect, El-Baz et al (2002) found that Vines pruned to 3 or 6 buds/cane resulted in higher significant values of $\mathrm{N}$ than pruning at 4 or 5 buds/cane during both tested seasons. However, nitrogen percentage was not significantly affected by bud load in both seasons.

Pruning "Autumn Royal " grapevines to 42 buds /vine gave greater $\mathrm{C} / \mathrm{N}$ than other bud load (32, 52 and 60 buds/vine). Data of Table (3) showed clearly that vines pruned to 42 buds/spur with 3 eyes per spur resulted in higher significant values of $\mathrm{C} / \mathrm{N}$ than with 2 or 4 buds/spur. On the other hand, vines pruned to 60 buds/spur with 3 eyes showed a lower $\mathrm{C} / \mathrm{N}$. Omar \& Abdel-kawi (2000) reported that Thompson Seedless grapevine which was pruned so as to leave 60 to 90 buds accumulated higher content of total carbohydrates than those pruned leaving 48 and 120 buds per vine.

Data from the same table showed that the yield/ vine was significantly reduced by increasing bud load. This decrease in vine yield may be attributed to decreased in weight of clusters/ vine with increasing bud load. Leaving 60 buds/ vine gave a lower significantly of yield/ vine which recorded (13.19 \& 12.43 and 11.65) with 2, 3 and 4 eyes per spur, respectively. Whereas leaving 42 buds/ vine gave a highest significantly increase of yield/ vine which recorded (16.64 \& $16.46 \mathrm{Kg} /$ vine with 2 and 3 eyes per spur during first season . Similar results ware observed by Omar and Abdel-kawi (2000). reported that bunch weight decreased by increasing bud load per vine of Thompson seedless. Furthermore, clusters weight values were highest in vine pruned to 56 buds/vine.

\section{Chemical analysis}


Arab Univ. J. Agric. Sci., Ain Shams Univ., Cairo, 23(1), 51 - 60, 2015

Table 2. Effeet of vine bud load and spur length on bud behaviour of " Autumn Royal " grapevines in 2013 and 2014 seasons

\begin{tabular}{|c|c|c|c|c|c|c|c|c|c|}
\hline \multicolumn{2}{|c|}{ Treatment } & \multicolumn{2}{|c|}{ Bursted buds (\%) } & \multicolumn{2}{c|}{ Fertitity buds (\%) } & \multicolumn{2}{|c|}{ leaf area $\mathbf{( c m}^{\mathbf{2}}$ ) } & \multicolumn{2}{c|}{ Chlorophyll $\mathbf{~ m g / m 2 ~}$} \\
\hline \multirow{2}{*}{ BL } & $\mathbf{L}$ & $\begin{array}{c}\mathbf{1}^{\text {st }} \\
\text { season }\end{array}$ & $\begin{array}{c}\mathbf{2}^{\text {nd }} \\
\text { season }\end{array}$ & $\begin{array}{c}\mathbf{1}^{\text {st }} \\
\text { season }\end{array}$ & $\begin{array}{c}\mathbf{2}^{\text {nd }} \\
\text { season }\end{array}$ & $\begin{array}{c}\mathbf{1}^{\text {st }} \\
\text { season }\end{array}$ & $\begin{array}{c}\mathbf{2}^{\text {nd }} \\
\text { season }\end{array}$ & $\begin{array}{c}\mathbf{1}^{\text {st }} \\
\text { season }\end{array}$ & $\begin{array}{c}\mathbf{2}^{\text {nd }} \\
\text { season }\end{array}$ \\
\hline \multirow{2}{*}{32} & 2 & $90.27 \mathrm{bc}$ & $92.85 \mathrm{a}-\mathrm{d}$ & $85.64 \mathrm{ab}$ & $87.00 \mathrm{ab}$ & $118.7 \mathrm{~b}$ & $116.0 \mathrm{a}-\mathrm{d}$ & $357.6 \mathrm{a}$ & $356.8 \mathrm{bc}$ \\
& 3 & $90.20 \mathrm{bc}$ & $93.31 \mathrm{a}-\mathrm{d}$ & $85.10 \mathrm{ab}$ & $86.52 \mathrm{~b}$ & $126.2 \mathrm{ab}$ & $118.8 \mathrm{a}-\mathrm{c}$ & $365.9 \mathrm{a}$ & $379.1 \mathrm{a}$ \\
& 4 & $91.31 \mathrm{a}-\mathrm{c}$ & $92.41 \mathrm{~b}-\mathrm{d}$ & $87.70 \mathrm{ab}$ & $87.23 \mathrm{ab}$ & $124.6 \mathrm{ab}$ & $112.9 \mathrm{~b}-\mathrm{e}$ & $355.5 \mathrm{ab}$ & $365.1 \mathrm{ab}$ \\
\hline \multirow{2}{*}{42} & 2 & $95.88 \mathrm{a}$ & $96.92 \mathrm{a}$ & $86.07 \mathrm{ab}$ & $88.64 \mathrm{ab}$ & $109.3 \mathrm{c}$ & $116.7 \mathrm{a}-\mathrm{d}$ & $347.2 \mathrm{a}-\mathrm{c}$ & $349.5 \mathrm{~b}-\mathrm{d}$ \\
& 3 & $95.22 \mathrm{ab}$ & $96.18 \mathrm{a}$ & $88.40 \mathrm{a}$ & $90.13 \mathrm{a}$ & $128.3 \mathrm{a}$ & $124.1 \mathrm{a}$ & $336.8 \mathrm{a}-\mathrm{d}$ & $349.5 \mathrm{~b}-\mathrm{d}$ \\
& 4 & $94.87 \mathrm{ab}$ & $95.76 \mathrm{ab}$ & $86.60 \mathrm{ab}$ & $89.36 \mathrm{ab}$ & $127.7 \mathrm{ab}$ & $121.2 \mathrm{ab}$ & $336.8 \mathrm{a}-\mathrm{d}$ & $354.7 \mathrm{bc}$ \\
\hline \multirow{2}{*}{52} & 2 & $93.83 \mathrm{a}-\mathrm{c}$ & $94.79 \mathrm{a}-\mathrm{c}$ & $84.57 \mathrm{ab}$ & $85.10 \mathrm{~b}$ & $94.6 \mathrm{de}$ & $110.3 \mathrm{c}-\mathrm{e}$ & $336.8 \mathrm{a}-\mathrm{d}$ & $349.5 \mathrm{~b}-\mathrm{d}$ \\
& 3 & $93.98 \mathrm{a}-\mathrm{c}$ & $93.23 \mathrm{a}-\mathrm{d}$ & $87.10 \mathrm{ab}$ & $86.60 \mathrm{~b}$ & $97.9 \mathrm{de}$ & $113.3 \mathrm{~b}-\mathrm{e}$ & $324.3 \mathrm{c}-\mathrm{e}$ & $351.6 \mathrm{bc}$ \\
& 4 & $92.93 \mathrm{a}-\mathrm{c}$ & $92.97 \mathrm{a}-\mathrm{d}$ & $82.25 \mathrm{bc}$ & $84.83 \mathrm{bc}$ & $103.9 \mathrm{~cd}$ & $110.7 \mathrm{c}-\mathrm{e}$ & $326.4 \mathrm{~b}-\mathrm{e}$ & $370.3 \mathrm{~b}$ \\
\hline \multirow{2}{*}{60} & 2 & $90.85 \mathrm{c}$ & $91.67 \mathrm{~cd}$ & $82.85 \mathrm{bc}$ & $83.54 \mathrm{c}$ & $96.2 \mathrm{de}$ & $112.7 \mathrm{~b}-\mathrm{e}$ & $305.6 \mathrm{e}$ & $339.1 \mathrm{c}-\mathrm{e}$ \\
& 3 & $91.31 \mathrm{c}$ & $91.52 \mathrm{~cd}$ & $81.56 \mathrm{bc}$ & $84.48 \mathrm{bc}$ & $82.10 \mathrm{f}$ & $108.9 \mathrm{de}$ & $323.9 \mathrm{e}$ & $320.4 \mathrm{de}$ \\
& 4 & $90.71 \mathrm{c}$ & $90.63 \mathrm{~d}$ & $80.95 \mathrm{c}$ & $83.54 \mathrm{c}$ & $82.43 \mathrm{f}$ & $105.8 \mathrm{e}$ & $298.3 \mathrm{e}$ & $318.3 \mathrm{e}$ \\
\hline
\end{tabular}

* values followed by the same letters within each column are not significantly different at $5 \%$ level according to Duncan's Multiple range test. $\quad B L=$ Bud load number of eyes per vine $\quad L=$ number of eyes per spur

Table 3. Effect of vine bud load spur length on Chemical analysis and yield of " Autumn Royal " grapevines in 2013 and 2014 seasons

\begin{tabular}{|c|c|c|c|c|c|c|c|c|c|}
\hline \multicolumn{2}{|c|}{ Treatment } & \multicolumn{2}{|c|}{$\begin{array}{c}\text { Total carbohydrates } \\
\%\end{array}$} & \multicolumn{2}{c|}{$\begin{array}{c}\text { Total nitrogen } \\
\%\end{array}$} & \multicolumn{2}{c|}{ C/N ratio } & \multicolumn{2}{c|}{ Yield (kg)/ vine } \\
\hline \multirow{2}{*}{ NL } & $\mathbf{L}$ & $\begin{array}{c}\mathbf{1}^{\text {st }} \\
\text { season }\end{array}$ & $\begin{array}{c}\mathbf{2}^{\text {nd }} \\
\text { season }\end{array}$ & $\begin{array}{c}1^{\text {st }} \\
\text { season }\end{array}$ & $\begin{array}{c}\mathbf{2}^{\text {nd }} \\
\text { season }\end{array}$ & $\begin{array}{c}\mathbf{1}^{\text {st }} \\
\text { season }\end{array}$ & $\begin{array}{c}\mathbf{2}^{\text {nd }} \\
\text { season }\end{array}$ & $\begin{array}{c}1^{\text {st }} \\
\text { season }\end{array}$ & $\begin{array}{c}\mathbf{2}^{\text {nd }} \\
\text { season }\end{array}$ \\
\hline \multirow{2}{*}{32} & 2 & $17.30 \mathrm{ab}$ & $17.14 \mathrm{ab}$ & $2.92 \mathrm{ab}$ & $2.88 \mathrm{a}$ & $5.92 \mathrm{c}$ & $5.95 \mathrm{~b}$ & $16.39 \mathrm{bc}$ & $14.50 \mathrm{bc}$ \\
& 3 & $16.83 \mathrm{ab}$ & $17.04 \mathrm{ab}$ & $2.96 \mathrm{a}$ & $2.84 \mathrm{ab}$ & $5.69 \mathrm{c}$ & $6.00 \mathrm{~b}$ & $15.43 \mathrm{bc}$ & $14.84 \mathrm{ab}$ \\
& 4 & $16.70 \mathrm{ab}$ & $16.94 \mathrm{ab}$ & $2.64 \mathrm{~b}$ & $2.80 \mathrm{ab}$ & $6.33 \mathrm{bc}$ & $6.05 \mathrm{~b}$ & $14.32 \mathrm{de}$ & $14.82 \mathrm{ab}$ \\
\hline \multirow{2}{*}{42} & 2 & $16.77 \mathrm{ab}$ & $16.93 \mathrm{ab}$ & $2.92 \mathrm{ab}$ & $2.76 \mathrm{ab}$ & $5.74 \mathrm{c}$ & $6.13 \mathrm{ab}$ & $16.64 \mathrm{a}$ & $15.53 \mathrm{a}$ \\
& 3 & $17.66 \mathrm{a}$ & $17.21 \mathrm{a}$ & $2.80 \mathrm{ab}$ & $2.72 \mathrm{ab}$ & $6.31 \mathrm{bc}$ & $6.33 \mathrm{ab}$ & $16.46 \mathrm{a}$ & $15.16 \mathrm{ab}$ \\
& 4 & $16.95 \mathrm{ab}$ & $16.88 \mathrm{ab}$ & $2.64 \mathrm{~b}$ & $2.68 \mathrm{ab}$ & $6.42 \mathrm{bc}$ & $6.30 \mathrm{ab}$ & $15.67 \mathrm{ab}$ & $14.68 \mathrm{bc}$ \\
\hline \multirow{2}{*}{52} & 2 & $16.94 \mathrm{ab}$ & $16.77 \mathrm{ab}$ & $2.56 \mathrm{~b}$ & $2.56 \mathrm{~b}$ & $6.62 \mathrm{bc}$ & $6.55 \mathrm{ab}$ & $14.61 \mathrm{c}-\mathrm{e}$ & $13.89 \mathrm{~cd}$ \\
& 3 & $16.57 \mathrm{ab}$ & $16.58 \mathrm{ab}$ & $2.64 \mathrm{~b}$ & $2.68 \mathrm{ab}$ & $6.28 \mathrm{bc}$ & $6.19 \mathrm{ab}$ & $14.94 \mathrm{~b}-\mathrm{d}$ & $13.03 \mathrm{~cd}$ \\
& 4 & $16.53 \mathrm{~b}$ & $16.74 \mathrm{ab}$ & $2.44 \mathrm{~b}$ & $2.60 \mathrm{~b}$ & $6.77 \mathrm{ab}$ & $6.44 \mathrm{ab}$ & $13.49 \mathrm{ef}$ & $12.94 \mathrm{~cd}$ \\
\hline \multirow{2}{*}{60} & 2 & $16.26 \mathrm{~b}$ & $16.72 \mathrm{ab}$ & $2.48 \mathrm{~b}$ & $2.68 \mathrm{ab}$ & $6.56 \mathrm{bc}$ & $6.24 \mathrm{ab}$ & $13.19 \mathrm{ef}$ & $11.76 \mathrm{e}$ \\
& 3 & $17.24 \mathrm{ab}$ & $16.55 \mathrm{ab}$ & $2.36 \mathrm{bc}$ & $2.56 \mathrm{~b}$ & $7.31 \mathrm{ab}$ & $6.46 \mathrm{ab}$ & $12.43 \mathrm{f}$ & $12.53 \mathrm{de}$
\end{tabular}


\begin{tabular}{|l|l|l|l|l|l|l|l|l|l|}
\hline & 4 & $16.28 \mathrm{~b}$ & $16.32 \mathrm{~b}$ & $2.11 \mathrm{c}$ & $2.32 \mathrm{~b}$ & $7.72 \mathrm{a}$ & $7.03 \mathrm{a}$ & $11.65 \mathrm{f}$ & $12.66 \mathrm{de}$ \\
\hline
\end{tabular}

* values followed by the same letters within each column are not significantly different at $5 \%$ level according to Duncan's Multiple range test. $\quad B L=$ Bud load number of eyes per vine $\quad \mathrm{L}=$ number of eyes per spur

\section{Physical berry characteristics}

Data in Table (4) indicated that increasing the bud load/ vine reduced the average weight of cluster, thus, average cluster weight was least in vines pruned to 60 buds/ vine. These results agreed with those findings of Abdel-Fattah, et al (1993) and Rizk et al (1994). El-Hammady \& Abdel- Hamid, 1995) and Omar \& Abdel-kawi (2000) reported that bunch weight decreased by increasing bud load per vine of Thompson seedless. Furthermore, clusters weight values were highest in vine pruned to 42 buds/vine. Moreover, the highest cluster weight was obtained by those vine pruned to 42 buds/ vine \& 3 buds/ cane which recorded (503.6 \& $558.3 \mathrm{~g}$ ) in the two seasons, respectively.

Also, data of Table (4) show the effect of different bud load/ vine and spur length on Shot berries/cluster \% of "Autumn Royal". Thus it is appeared to increase by increasing the bud load on the vine. In this respect, vines which were pruned to 60 buds/ vine maintained the highest value of shoot berries during the both seasons of this study. Yet, there are no clear differences on the shoot berries that had been obtained by leaving different spur length.

It is also clear from Table (4) that leaving 52 or 60 buds/vine gave a slight increase in clusters compactness coefficient, without significantly differences among them. In that respect, El-Baz et al (2002) reported that pruning severity did not affect their compactness coefficient on Crimson Seedless. However, vines pruned to 42 buds/vine plus 2 and 3 eyes had recorded the lowest values of cluster compactness it recorded (3.78 \& 3.88) in the first seasons, respectively.

This means that bud load of 42 buds/vine is stubble for grape vines to good yield and slight compactness of cluster. Moreover, cluster of "Autumn Royal" are medium in length and therefore are slight compact. These results in this connection agree with those obtained by Ramming et al (1995) on Crimson seedless.

As for firmness $\left(\mathrm{g} / \mathrm{cm}^{2}\right)$ it is clear that, the highest value was found for vines to 42 buds / vine and 3 buds/canespur, Data recorded (1120 and 1005) in the two seasons 2013 and 2014, respectively. Data indicated that firmness was significantly decreased by increasing spur length. In this connec- tion, vines which were pruned to 2 buds /spur appeared to higher firmness than the other cane length.

Concerning Berry juice \%, it is clear that the highest values was found for vines pruned to 42 buds/vine \& 3 buds/ spur it recorded $(81.75$ and $75.50 \%)$ in the two seasons, respectively this increase could be attributed to the increases in cluster weight at this treatment.

\section{Chemical berry characteristics}

From Table (5) it is clear that vines pruned to 42 buds/vine \& 3 buds/cane gave the highest significant values concerning T.S.S\%. This treatment recorded (19.4\%) during 2013. In second seasons, Vines pruned to 52 buds/vine \& 2 buds/vine recorded the highest value in this respect (17.55\%). Vines pruned to 60 buds/vine \& 4 buds /cane gave the lower values, which recorded (16.60 \& 14.25 $\%)$ in the two seasons, respectively. The results agreed with those findings by Ramming et al (1995) who indicated that T.S.S\% was not affected markedly by pruning levels of Crimson seedless.

As same table, it is evident that acidity \% was a slight increased by increasing bud load/vine. Vines pruned to 60 buds/ vine with 4 eyes per spur recorded the highest values of acidity \% where it was $(0.45 \& 0.43 \%)$ in the two seasons, respectively. In this respect, El-Baz et al (2002) found that leaving to 10 canes/ vine gave a slight increment of acidity $\%$ in berry juice than above that maintained on leaving 8canes/ vine but the differences between them were not significant. Yet, vines pruned to 8 canes with 12 nodes produced a lower total acidity $\%$ than the other pruning severity of Crimson seedless grapevines. Although, number of buds per bearing unit had no significant effect on TA\% in first season but there are slight effect in the second season. These results in this respect are harmony with the findings found of Fawzi et al (1984 b) reported that titratable acidity of Thompson Seedless was not affect under canes were pruned to different number of buds (12; 18 and 24 buds per cane). Also, Ramming et al (1995) and El-Hammady \& Abdel- Hamid, 1995) mentioned that, pruning levels gave no clear effect on the titratable acidity of berry juice of Crimson seedless.

It is clear from data, the effect bud load /vine and length spur on T.S.S/ acid ratio similar to that concerning in total soluble solids. 
The greatest content of anthocyanine (39.7 and $36.8 \mathrm{mg} / 100 \mathrm{~g} \mathrm{f.wt}$.) were cleared with pruned vine with 42 buds +2 and 3 eyes / spur respectively with slight differences between them. Wherease, the vine pruned with 42 buds + all number eyes of Table 4. Effect of vine bud load spur length on some physical berry characteristics of " Autumn Royal" grapevines in 2013 and 2014 seasons

\begin{tabular}{|c|c|c|c|c|c|c|c|c|c|c|c|}
\hline \multicolumn{2}{|c|}{ Treatment } & \multicolumn{2}{|c|}{$\begin{array}{l}\text { Cluster weight } \\
\text { (g) }\end{array}$} & \multicolumn{2}{|c|}{$\begin{array}{c}\text { Shot berries } \\
\%\end{array}$} & \multicolumn{2}{|c|}{$\begin{array}{l}\text { Compactness } \\
\text { coefficient }\end{array}$} & \multicolumn{2}{|c|}{$\begin{array}{l}\text { Berry firmness } \\
\mathrm{g} / \mathrm{cm}\end{array}$} & \multicolumn{2}{|c|}{$\begin{array}{c}\text { berry juice } \\
\%\end{array}$} \\
\hline BL & $\mathbf{L}$ & $\begin{array}{c}1^{\text {st }} \\
\text { season }\end{array}$ & $\begin{array}{c}2^{\text {nd }} \\
\text { season }\end{array}$ & $\begin{array}{c}1^{\text {st }} \\
\text { season }\end{array}$ & $\begin{array}{c}2^{\text {nd }} \\
\text { season }\end{array}$ & $\begin{array}{c}1^{\text {st }} \\
\text { season }\end{array}$ & \begin{tabular}{|c|}
$2^{\text {nd }}$ \\
season \\
\end{tabular} & $\begin{array}{c}1^{\text {st }} \\
\text { season } \\
\end{array}$ & $\begin{array}{c}2^{\text {nd }} \\
\text { season }\end{array}$ & $\begin{array}{c}1^{\text {st }} \\
\text { season }\end{array}$ & $\begin{array}{c}2^{\text {nd }} \\
\text { season }\end{array}$ \\
\hline \multirow{3}{*}{32} & 2 & 41 & $520.5 b$ & 4.6 & e & $5.11 \mathrm{a}$ & $6.17 \mathrm{a}$ & 918 bc & 1025 b & $72.50 \mathrm{c}$ & $73.75 \mathrm{~b}$ \\
\hline & 3 & $427 . .3 \mathrm{~b}$ & $521.3 b$ & 3.48 & $4.975 \mathrm{e}$ & $4.93 \mathrm{ab}$ & $5.47 \mathrm{ab}$ & $890 \mathrm{c}$ & $990 \mathrm{~b}$ & $79.50 \mathrm{~b}$ & $70.00 \mathrm{c}$ \\
\hline & 4 & $434.5 \mathrm{~b}$ & $528.3 \mathrm{~b}$ & $4.55 \mathrm{e}$ & $4.80 \mathrm{e}$ & $5.06 \mathrm{ab}$ & $5.66 \mathrm{ab}$ & $885 \mathrm{c}$ & $985 \mathrm{~b}$ & $77.56 \mathrm{~b}$ & $68.75 \mathrm{~cd}$ \\
\hline \multirow[t]{3}{*}{42} & 2 & $412.3 \mathrm{c}$ & $500.8 \mathrm{c}$ & 3.95 ef & $5.82 \mathrm{de}$ & $3.78 \mathrm{c}$ & $4.37 \mathrm{c}$ & $942 b$ & $1053 a b$ & $71.50 \mathrm{c}$ & $70.50 \mathrm{c}$ \\
\hline & 3 & $503.6 \mathrm{a}$ & $558.3 \mathrm{a}$ & $4.68 \mathrm{e}$ & $4.60 \mathrm{e}$ & $3.88 \mathrm{c}$ & $4.53 \mathrm{c}$ & $1120 \mathrm{a}$ & $1005 \mathrm{a}$ & $81.75 \mathrm{a}$ & $75.50 \mathrm{a}$ \\
\hline & 4 & $397.8 d$ & $523.8 \mathrm{~b}$ & $2.83 \mathrm{f}$ & $4.95 \mathrm{e}$ & $4.02 \mathrm{bc}$ & $4.05 c$ & 925 bc & $1038 \mathrm{~b}$ & $69.25 \mathrm{~cd}$ & $71.73 \mathrm{bc}$ \\
\hline \multirow[t]{3}{*}{52} & 2 & $375.0 \mathrm{e}$ & $478.5 \mathrm{~d}$ & $8.25 \mathrm{~d}$ & $7.95 \mathrm{c}$ & $4.43 \mathrm{~b}$ & $4.79 \mathrm{bc}$ & $880 \mathrm{c}$ & $995 \mathrm{~b}$ & $68.50 \mathrm{~cd}$ & $72.15 b$ \\
\hline & 3 & 3687.0 ef & $450.8 d$ & $7.11 \mathrm{~d}$ & $7.26 \mathrm{~cd}$ & $4.50 \mathrm{~b}$ & $5.07 \mathrm{bc}$ & $825 d$ & $920 \mathrm{c}$ & $66.75 \mathrm{~cd}$ & $66.50 \mathrm{de}$ \\
\hline & 4 & $3682.3 \mathrm{f}$ & $380.0 \mathrm{e}$ & $11.23 \mathrm{c}$ & $6.93 \mathrm{~cd}$ & $4.62 \mathrm{~b}$ & $4.79 \mathrm{bc}$ & 800 de & $895 \mathrm{~cd}$ & $65.00 \mathrm{~d}$ & $69.00 \mathrm{~cd}$ \\
\hline \multirow[t]{3}{*}{60} & 2 & $359.3 \mathrm{fg}$ & 384.0 ef & $14.88 \mathrm{ab}$ & $13.15 \mathrm{a}$ & $4.24 \mathrm{~b}$ & $5.35 b$ & 783 de & $865 \mathrm{~cd}$ & $63.25 \mathrm{de}$ & $65.00 \mathrm{e}$ \\
\hline & 3 & $348.0 \mathrm{~g}$ & 378.0 ef & $15.98 \mathrm{a}$ & $11.42 \mathrm{~b}$ & $4.28 \mathrm{~b}$ & $4.68 \mathrm{bc}$ & 757 e & $835 d$ & $65.75 d$ & $66.00 \mathrm{de}$ \\
\hline & 4 & $338.5 \mathrm{~g}$ & $357.0 \mathrm{f}$ & $14.27 \mathrm{~b}$ & $12.15 \mathrm{ab}$ & $4.14 \mathrm{~b}$ & $4.58 \mathrm{bc}$ & 753 e & $823 d$ & $59.50 \mathrm{e}$ & $64.75 \mathrm{e}$ \\
\hline
\end{tabular}

* values followed by the same letters within each column are not significantly different at $5 \%$ level according to Duncan's Multiple range test. $\quad B L=$ Bud load number of eyes per vine $\quad L=$ number of eyes per spur

Table 5. Effect of vine bud load spur length on some chemical berry characteristics of "Autumn Royal" grapevines in 2013 and 2014 seasons

\begin{tabular}{|c|c|c|c|c|c|c|c|c|c|}
\hline \multicolumn{2}{|c|}{ Treatment } & \multicolumn{2}{|c|}{ TSS\% } & \multicolumn{2}{c|}{ TA\% } & \multicolumn{2}{c|}{ T.S.S/acid ratios } & \multicolumn{2}{c|}{$\begin{array}{c}\text { Total anthocyanin } \\
\text { (mg/100 g fresh weight) }\end{array}$} \\
\hline \multirow{2}{*}{ BL } & $\mathbf{L}$ & $\begin{array}{c}\mathbf{1}^{\text {st }} \\
\text { season }\end{array}$ & $\begin{array}{c}\mathbf{2}^{\text {nd }} \\
\text { season }\end{array}$ & $\begin{array}{c}\mathbf{1}^{\text {st }} \\
\text { season }\end{array}$ & $\begin{array}{c}\mathbf{2}^{\text {nd }} \\
\text { season }\end{array}$ & $\begin{array}{c}\mathbf{1}^{\text {st }} \\
\text { season }\end{array}$ & $\begin{array}{c}\mathbf{2}^{\text {nd }} \\
\text { season }\end{array}$ & $\begin{array}{c}\mathbf{1}^{\text {st }} \\
\text { season }\end{array}$ & $\begin{array}{c}\mathbf{2}^{\text {nd }} \\
\text { season }\end{array}$ \\
\hline \multirow{2}{*}{32} & 2 & $16.95 \mathrm{~b}-\mathrm{d}$ & $16.50 \mathrm{ab}$ & $0.37 \mathrm{ab}$ & $0.36 \mathrm{~b}$ & $45.81 \mathrm{~cd}$ & $44.44 \mathrm{~cd}$ & $38.63 \mathrm{~cd}$ & $39.42 \mathrm{~cd}$ \\
& 3 & $16.85 \mathrm{~b}-\mathrm{d}$ & $16.40 \mathrm{ab}$ & $0.39 \mathrm{ab}$ & $0.36 \mathrm{~b}$ & $43.21 \mathrm{de}$ & $45.56 \mathrm{c}$ & $40.60 \mathrm{bc}$ & $39.05 \mathrm{~cd}$ \\
& 4 & $17.48 \mathrm{~b}-\mathrm{d}$ & $16.60 \mathrm{ab}$ & $0.35 \mathrm{~b}$ & $0.33 \mathrm{c}$ & $49.94 \mathrm{bc}$ & $50.30 \mathrm{~b}$ & $40.33 \mathrm{bc}$ & $42.05 \mathrm{c}$ \\
\hline \multirow{2}{*}{42} & 2 & $17.10 \mathrm{~b}-\mathrm{d}$ & $16.85 \mathrm{ab}$ & $0.33 \mathrm{~b}$ & $0.30 \mathrm{~cd}$ & $51.82 \mathrm{~b}$ & $56.17 \mathrm{a}$ & $46.50 \mathrm{a}$ & $48.00 \mathrm{a}$ \\
& 3 & $19.40 \mathrm{a}$ & $16.85 \mathrm{ab}$ & $0.34 \mathrm{~b}$ & $0.30 \mathrm{~cd}$ & $64.64 \mathrm{a}$ & $55.0 \mathrm{ab}$ & $44.13 \mathrm{ab}$ & $44.72 \mathrm{~b}$ \\
& 4 & $18.42 \mathrm{a}-\mathrm{c}$ & $16.95 \mathrm{ab}$ & $0.30 \mathrm{bc}$ & $0.31 \mathrm{~cd}$ & $61.40 \mathrm{a}$ & $54.68 \mathrm{ab}$ & $41.65 \mathrm{bc}$ & $44.63 \mathrm{~b}$ \\
\hline \multirow{2}{*}{52} & 2 & $18.58 \mathrm{ab}$ & $17.55 \mathrm{a}$ & $0.29 \mathrm{c}$ & $0.40 \mathrm{ab}$ & $46.45 \mathrm{~cd}$ & $43.88 \mathrm{c}$ & $40.80 \mathrm{bc}$ & $43.72 \mathrm{bc}$ \\
& 3 & $16.85 \mathrm{~b}-\mathrm{d}$ & $16.60 \mathrm{ab}$ & $0.31 \mathrm{bc}$ & $0.42 \mathrm{a}$ & $54.35 \mathrm{~b}$ & $41.50 \mathrm{~cd}$ & $37.10 \mathrm{de}$ & $42.50 \mathrm{bc}$ \\
& 4 & $16.70 \mathrm{~cd}$ & $15.40 \mathrm{~b}$ & $0.32 \mathrm{bc}$ & $0.29 \mathrm{~d}$ & $52.19 \mathrm{~b}$ & $53.10 \mathrm{ab}$ & $37.22 \mathrm{de}$ & $35.55 \mathrm{de}$ \\
\hline \multirow{2}{*}{60} & 2 & $15.85 \mathrm{~d}$ & $15.90 \mathrm{~b}$ & $0.40 \mathrm{ab}$ & $0.43 \mathrm{a}$ & $36.86 \mathrm{f}$ & $46.0 \mathrm{c}$ & $34.58 \mathrm{e}$ & $35.47 \mathrm{de}$
\end{tabular}




\begin{tabular}{|c|c|c|c|c|c|c|c|c|c|}
3 & $16.20 \mathrm{~d}$ & $14.55 \mathrm{bc}$ & $0.43 \mathrm{a}$ & $0.42 \mathrm{a}$ & $38.57 \mathrm{ef}$ & $36.64 \mathrm{de}$ & $36.45 \mathrm{de}$ & $33.85 \mathrm{e}$ \\
& 4 & $16.60 \mathrm{~d}$ & $14.25 \mathrm{c}$ & $0.45 \mathrm{a}$ & $0.42 \mathrm{a}$ & $39.52 \mathrm{~b}$ & $33.93 \mathrm{e}$ & $36.17 \mathrm{de}$ & $34.03 \mathrm{e}$ \\
\hline
\end{tabular}

* values followed by the same letters within each column are not significantly different at $5 \%$ level according to Duncan's Multiple range test. $\quad \mathrm{BL}=$ Bud load number of eyes per vine $\mathrm{L}=$ number of eyes per spur

From the obtained data in this study, it could be concluded that the suitable bud load per vine for Autumn Royal grapes was 42 buds to produce high yield with good quality and maintaining the vigor of the vine. On the other hand, improved bunch properties were noted in spur pruned to 2 or 3 nodes than rest of the treatments.

\section{REFERANCES}

A.O.A.C. 1980. Official methods of analysis Association of Official Agricultural Chemists13th ed., Washington 499 D.C., USA.

Abdel-Fattah, S.E., Marwad, I.A. and Rizk, I.A. 1993. Effect of bud load and spur length on Roumi Red grapevine I-Weight of pruning and chemical compostion of 1 year - old wood. Zagazig. J. Agric. Res 2(6): 1889 -1899.

Ahmad, W., Junaid, M., Nafees, M., Farooq, M. and Sallem, B.A. 2004. Effect of pruning severity on growth behavior of spur and bunch morphology of grapes (vitis vinifera L.) cv. Perlette. International Journal of Agriculture and Biology, 6(1): 160-161.

Ali, M.A., El-Mogy, M.M. and Rizk, I. 2000. Effect of cane length on bud behaviour, bunch characteristics, wood ripening and chemical contents of thompson seedless grapevine. Agric. Sci., Mansoura Univ., 25 (3): 1707-1713.

Bodor, P., Baranyai, L., Ladányi, M., Bálo, B., Strever, A.E., Gy. D. Bisztray1 and Hunter, J.J. 2013. Stability of Ampelometric Characteristics of Vitis vinifera L. cv. 'Syrah' and 'Sauvignon blanc' Leaves: Impact of Within-vineyard Variability and Pruning Method/Bud Load. S. Afr. J. Enol. Vitic., 34(1): 173-181.

Brown, M. and Gao, G. 2004. Pruning Backyard Grapevines in the First Three Years. Horticulture and Crop Science, 2021 Coffey Road, Columbus, Ohio 43210 HYG-1429.

Cangi, R. and Kilic, D. 2011. Effects of bud loading levels and nitrogen doses on yield, Physical and chemical properties of brined grape leaves. African Journal of Biotechnology. 10(57): 12195-12201.

Cawthon, D.L. and Morris, J.R. 1977. Yield and quality of "Concord" grapes as affected by pruning severity, nodes per bearing unit, train- ing system, shoot positioning, and sampling date in Arkansas. J. Amer. Soc. Hort. Sci. 102(6): 760-767.

Christensen, L.P., Leavit, G.M. and Bianch, M.L. 1994. The effects of pruning level and post bud break cane adjustment on Thompson seedless raisin production and quality, Amer. J. Enel and vatic., 45(2): 141-148.

Di Lorenzo, R., Gambino, C. and Scafidi, P. 2011. Summer pruning in table grape. Adv. Hort. Sci., 25(3): 143-150.

El-Baz, El.El.T., Mansour, A.M.,. El-Dengawy, EI.F. and Samra, B.N. 2002. Influence of pruning severity on bud behaviour, yield, berry quality and some biochemical contents of the canes of "Crimson seedless" Grapes. Egypt. J. Hort. 29(1): 39-60.

Elbotaty, E.M.A. 2007. Effect of bud load and some horticultural practices on the productivity and fruit quality of Crimson grapevines. M. Sc. thesis, Fac. Agric., Ain Shams Univ., Cairo, Egypt.

EL-Hammady, A.M. and Abd El-Hamid, N. 1995. The Effect Of Vine Bud Load On Yield And Fruit Quality Of " King, Gapevines Annals Agric. Sci., Ain Shams Univ., Cairo , 40(1): $279-292$.

FAO, 2010. FAOSTAT: Statistical database. Food and Agriculture Organization of the United $\mathrm{Na}$ tions, Rome, Italy. http:// faostat. Fao.org/site/339/default.aspx

Fawzi, F., Bondok, A.Z. and Ghobrial, G.F. 1984b. Effect of cane length on cropping and some mechanical and chemical properties of bunches in "Thompson seedless" grape variety, Annals Agric., Sci., Ain Shams Univ., Cairo 29(1): 475-483.

Fawzi, F., Bondok, A.Z. and Ghobrial, G.F. 1984a. Effect of cane length on bud behaviour and wood ripening of Thompson seedless grape variety, Annals Agric., Sci., Ain Shams Univ., Cairo 29(1): 465-474.

Fawzi, M.I.F., Shahin, M.F.M. and Kandil, E.A. 2010. Effect of bud load on bud behavior, yield, cluster characteristics and some biochemical contents of the cane of Crimson seedless 
grapevines. Journal of American Science. 6(12): 187-194.

Herbert, D., Phipps, P.J. and Strange, R.F. 1971. Determination of total carbohydrates Methods in Microbian; 5(B): 209-244.

Marwad, I.A., Rizk, N.A. and Ibrahim, A.H. 1993. Effect of cane length on bud behaviour, Yield, bunch characteristics and wood maturity of Thompson seedless grapevines Egypt. J. Appl. Sci., 8(12): 47-60.

Monje, O.A. and Bugbee, B. 1992. Inherent limitations of nondestructive chlorophyll meters. A comparison of two types of meters. Hort. Science. 27: 69-71.

Morris, J.R., Cawthon, D.L. and Sims, C.A. 1984. Long-term effects of pruning severity, nodes per bearing unit, training system, and shoot positioning on yield and quality of "Concord" graps. J. Amer. Soc. Hort. Sci. 109(5): 676-683.

Murisier, F. and Ziegler, R. 1991. The effects of bud load planting density on the yield potential, grape quality and vegetative development. Trial on Chasselas. Hort. Abst., 62: 5651-5656.

Omar, A.H. and Abdel-kawi, A. 2000. Optimal bud load for Thompson seedless grapevines. J. Agric. Sci., Mansoura Univ. 25(9): 57695777.

Pregel, F. 1945. Quantitative organic microanalysis $4^{\text {th }}$ ed. J.A. Churchill. London.
Ramming, D.W., Tarailo, R. and Badr, S.A. 1995. "Crimson Seedless": A New Late-maturing, Red Seedless Grape. Hort Science, 30(7): 1473- 1474.

Rizk, N.A., Fizk, I.A. and Grigis, V.H. 1994. Effect of cane length on bud behavior, wood ripening and bunch characteristics of Thompson seedless grape Egypt. Jour. Appl. Zagazig Univ. Sci., 9(5): 230-239.

Salem, A.T., Kilani, A.S. and Shaker, G.S. 1997. Growth and quality of two grapevine cultivars as affected by pruning severity. Acta Hort. 441: 309-316.

Shalan, A.M. 2013. Performance of vitis unifera cultivar Flame Seedless grapevines under different node load per centimeter aquare of trunk cross-sectional area. Asian Journal of Crop Sciene 5(2):139-152.

Snedecor, G.A. and Cochran, W.G. 1982. Statistical Methods. $6^{\text {th }}$ ed the lowa state. Univ. press. lowa U.S.A. 